DOI https://doi.org/10.15589/znp2021.4(487).7

УДК 004.03

\title{
COMPUTER ENGINEERING IN INSURANCE COMPANIES
}

\section{КОМП'ЮТЕРНА ІНЖЕНЕРІЯ В СТРАХОВИХ КОМПАНІЯХ}

\author{
Valery G. Bondarenko ${ }^{1}$ \\ valery.bondarenko@gmail.com \\ ORCID: 0000-0002-5317-4632 \\ Pavel V. Bondarenko ${ }^{2}$ \\ pavel.bondarenko@gmail.com \\ ORCID: 0000-0002-8000-1913
}

\author{
В. Г. Бондаренко, \\ старший викладач
}

П. В. Бондаренко,

старший викладач

\author{
Odesa National Academy of Food Technologies, Odesa ${ }^{1}$ \\ Одеська начіональна академія харчових технологій, м. Одеса \\ Odesa National Economic University, Odesa ${ }^{2}$ \\ Одеський національний економічний університет, м. Одеса
}

\begin{abstract}
Purpose. Insurance - a set of special closed redistributive relations between its participants on the formation of cash contributions of the target insurance fund, designed to reimburse possible expenses of economic entities or losses of family budgets due to the consequences of insured events.

The main direction of improving information processing in insurance companies today is the creation of an automated information system based on the use of economic and mathematical methods, computer technology and a developed data network.

Thus, the purpose of the automated information system "Insurance" is to ensure the collection, storage, processing and transmission of information based on the use of computer technology and communications, taking into account the interaction of management levels and divisions of insurance companies among themselves, customers. Organizations and automated information systems of other ministries and departments, the NBU on insurance supervision.

Method. Method of analytical coefficients, horizontal analysis, analysis of absolute and relative indicators, equalization analysis, method of economic and mathematical modeling.

Results. Conceptual approaches to the automated information system "Insurance" are generalized. Methodical approaches to the use of the automated information system "Insurance" are determined.

The modern influence of external factors on the structure of the automated information system of insurance companies is revealed and their potential is analyzed. Computer engineering and financial technologies as a factor in the formation of the automated information system "Insurance" are revealed.

Scientific novelty. It consists of scientific conclusions, proposals and recommendations developed by the authors, which together solve an important scientific task: deepening the theoretical foundations of management of automated information system "Insurance" and substantiation of scientific and methodological recommendations for its improvement.

Practical importance. The application of computer engineering techniques in insurance companies is of interest to many, primarily as an environment for business operations. To date, it is almost impossible to deliver a policy in Ukraine within 24 hours after signing it (as required by the Civil Code), and it is almost impossible to unambiguously identify the user on the Internet, all this does not allow the development of remote insurance. (4 steps). But we should not stop and those insurance companies that today will lose their chance and will not "celebrate" on the Internet, tomorrow will not be able to work effectively.
\end{abstract}

Key words: computer engineering; financial engineering; insurance business; computer modeling; economic and mathematical modeling.

Анотація. Мета. Страхування - сукупність спеціальних закритих перерозподільних відносин між його учасниками щодо формування грошових внесків цільового страхового фонду, призначених для відшкодування можливих витрат суб'єктів господарювання або втрат сімейних бюджетів унаслідок страхових випадків.

Нині основним напрямом удосконалення обробки інформації в страхових компаніях є створення автоматизованої інформаційної системи на основі використання економіко-математичних методів, обчислювальної техніки та розвиненої мережі передання даних. 


\section{КОМП'ЮТЕРНІ НАУКИ ТА ІНФОРМАЦІЙНІ ТЕХНОЛОГІЇ № 4-2021}

Таким чином, метою автоматизованої інформаційної системи «Страхування» є забезпечення збирання, зберігання, оброблення та передання інформації на основі використання комп’ютерних технологій та засобів зв'язку з урахуванням взаємодії рівнів управління та підрозділів страхових компаній між собою, клієнтами, організаціями та автоматизованими інформаційними системами інших міністерств і відомств, НБУ щодо нагляду за страховою діяльністю.

Методика. Метод аналітичних коефіцієнтів, горизонтальний аналіз, аналіз абсолютних і відносних показників, порівняльний аналіз, метод економіко-математичного моделювання.

Результати. Узагальнено концептуальні підходи до автоматизованої інформаційної системи «Страхування». Визначено методичні підходи до використання автоматизованої інформаційної системи «Страхування».

Виявлено сучасний вплив зовнішніх факторів на структуру автоматизованої інформаційної системи страхових компаній та проаналізовано їх потенціал. Розкрито комп'ютерну інженерію та фінансові технології як чинник формування автоматизованої інформаційної системи «Страхування».

Наукова новизна полягає в розроблені авторами наукових висновків, пропозицій та рекомендацій, які в сукупності вирішують таке важливе наукове завдання, як поглиблення теоретичних засад управління автоматизованою інформаційною системою «Страхування» та обгрунтування науково-методичних рекомендацій щодо його вдосконалення.

Практична значимість. Застосування методики комп’ютерної інженерії в страхових компаніях цікавить багатьох як середовище для ділових операцій. Наразі доставити поліс в Україні протягом 24 годин після його підписання майже неможливо (як того вимагає Цивільний кодекс), а також майже неможливо однозначно ідентифікувати користувача в Інтернеті, що не дозволяє розвивати дистанційне страхування (4 кроки). Але не варто зупинятися, адже ті страхові компанії, які сьогодні втратять свій шанс і не будуть «святкуватися» в інтернет-просторі, завтра не зможуть ефективно працювати.

Ключові слова: комп'ютерна інженерія; фінансовий інжиніринг; страхова справа; комп'ютерне моделювання; економіко-математичне моделювання.

\section{ПОСТАНОВКА ЗАВДАННЯ}

Комп'ютерна інженерія (CoE або $\mathrm{CpE})$ - галузь інженерії, яка об'єднує кілька галузей інформатики та електронної інженерії, необхідних для розробки комп'ютерного обладнання та програмного забезпечення. Комп'ютерні інженери проходять підготовку в галузі електронної техніки (або електротехніки), розробки програмного забезпечення та інтеграції апаратного та програмного забезпечення, а не лише програмної чи електронної інженерії. Комп'ютерні інженери беруть участь у багатьох апаратних і програмних аспектах обчислювальної техніки (від проєктування окремих мікроконтролерів, мікропроцесорів, персональних комп'ютерів і суперкомп'ютерів до розробки схем). Ця сфера інженерії зосереджується не тільки на тому, як працюють самі комп'ютерні системи, а й на тому, як вони інтегруються в загальну картину.

Нині основним напрямом удосконалення обробки інформації в страхових компаніях є створення автоматизованої інформаційної системи, яка базується на використанні економіко-математичних методів, комп'ютерних технологій та розвиненої мережі передання даних.

3 огляду на вищевикладене, основною метою створення автоматизованої інформаційної системи в страховій компанії $є$ забезпечення такого рівня управління компанією, який комплексно реалізує такі завдання:

- проведення у встановлені терміни багатовимірних розрахунків, пов'язаних із рухом договорів страхування;

- автоматизація процесу обліку договорів 3 усіх видів страхування;
- досягнення максимальних темпів розвитку всіх видів майнового та особистого страхування;

- ухвалення оптимальних планових рішень щодо надходження та витрачання коштів, отримання необхідного прибутку.

Останній пункт найважливіший, оскільки страхові компанії $\epsilon$ комерційними та працюють за принципами повного економічного розрахунку [1].

\section{АНАЛІЗ ОСТАННІХ ДОСЛІДЖЕНЬ І ПУБЛІКАЦІЙ}

У цьому науковому напрямі, незважаючи на його актуальність, не так багато науковців, які займались цими питаннями, однак слід указати на К.М. Лаврищеву, яка опублікувала «Посібник із програмної інженерії», Ian Sommerville 3 його навчальним посібником "Software Engineering" i А.В. Островського та його публікацію «Інструментально-технологічний комплекс».

\section{ВИОКРЕМЛЕННЯ НЕ ВИРІШЕНИХ РАНІШЕ ЧАСТИН ЗАГАЛЬНОЇ ПРОБЛЕМИ}

Необхідність розвитку комп'ютерної інженерії у фінансових установах, зокрема страхових компаніях, дозволить прискорити всі економічні процеси як у підприємницькій діяльності, так і в Україні загалом. Також це підвищить рівень загальної диджиталізації й інформаційну культуру населення.

\section{МЕТА ДОСЛІДЖЕННЯ}

Мета статті - охарактеризувати особливості комп'ютерної інженерії в страховій компанії, проана- 
лізувати структуру роботи автоматизованих інформаційних систем у страховій компанії.

\section{МЕТОДИ, ОБ'СКТ ТА ПРЕДМЕТ ДОСЛІДЖЕННЯ}

Дослідження проводилось із використанням системного підходу й методів абстрагування, системного аналізу, порівняння, синтезу. Об'єктом дослідження є процеси комп'ютерної інженерії в страховій компанії. Предметом - відносини, які виникають щодо використання комп'ютерної інженерії в страховій компанії.

\section{ОСНОВНИЙ МАТЕРІАЛ}

Інформаційні системи на базі даних виготовляються на основі «коробкових» виробів або на замовлення і мають різні організаційні форми, як-от:

1. Ізольоване робоче місце спеціаліста страхової компанії.

2. Комплекс взаємопов'язаних робочих місць.

3. Ділова інформаційна система для автоматизації управління страховою компанією.

4. Автоматизоване робоче місце спеціаліста.

Кожне 3 цих автоматизованих робочих місць $\epsilon$ вузькоспеціалізованою інформаційною системою і, як правило, не має інформаційних та функціональних зв'язків з іншими робочими станціями.

Комплекси автоматизованих робочих місць об'єднані локальною мережею (рис. 1). Крім основних функцій страхової компанії, $є$ автоматизовані додаткові: бухгалтерське та податкове адміністрування, бізнес-аналіз, управління персоналом тощо. Усі автоматизовані робочі місця працюють в одному інформаційному просторі.

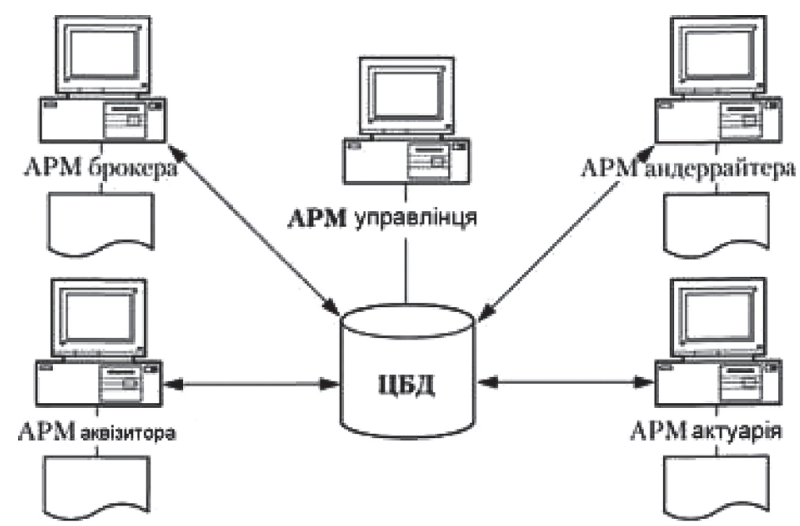

Рис. 1. Конфігурація центральної бази даних і комплексу APM [2]

Для компаній, що займаються широкомасштабною страховою діяльністю, мають філії, розвивають інформаційні бізнес-системи з базами даних, вони забезпечують централізоване управління компанією на основі нових інформаційних технологій (WiFi, WAP- i GPRS-технології, мобільні комп'ютери та пристрої, приватні мережі VPN тощо).
Корпоративні інформаційні системи мають функціональну завершеність і повноту системи управління, дозволяють оптимізувати ресурси компанії (фінансові та трудові), впроваджувати сучасні методи управління, як-от управління взаємовідносинами 3 клієнтами (CRM), управління людськими ресурсами (HRM), бізнес-аналітика Business Intelligence тощо.

Типова функціональна структура корпоративної IC:

1. Запровадження нормативно-правової бази системи страхування (довідники, класифікації технікоекономічної інформації, страхові тарифи).

2. Бізнес-планування страхової компанії.

3. Укладання та ведення договорів страхування (перестрахування).

4. Створення страхового фонду.

5. Обгрунтування розрахунків зі страхувальником (сплата страхових внесків, виплати за страховими подіями, розірвання договору страхування).

6. Бухгалтерський та податковий облік страхової компанії.

7. Аналіз фінансового стану страхової компанії.

8. Сервісні функції (імпорт та експорт даних, копіювання та відновлення бази даних) тощо.

Для побудови та впровадження CD IS страхової компанії, створеної на основі циркуляційних програмних продуктів, використовується модульний підхід і технологія налаштування функціональної структури CD IS. На рис. 2 представлена типова модель CD IS для страхових компаній.

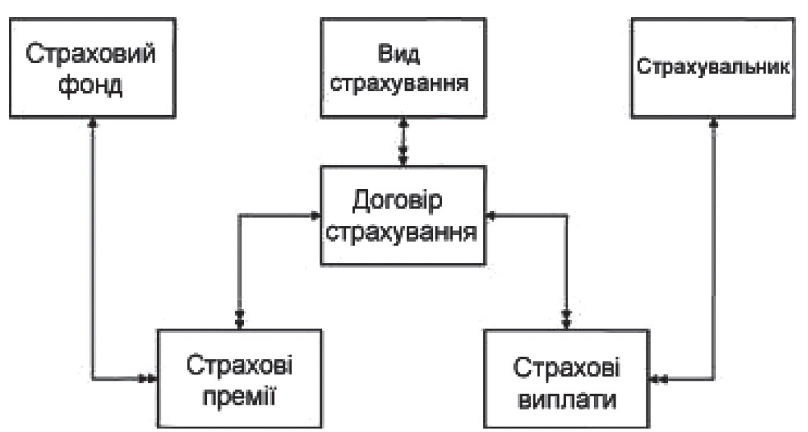

Рис. 2 Типова модель даних CD IS[2]

Етап збору та обліку інформації від страхової компанії пов'язаний із підготовкою значної кількості бланків документів (договорів, довідок, картотек, класифікацій, папок тощо). Як правило, крім традиційного документообігу, використовують електронні форми та організований електронний документообіг. Для автоматизації збору та обліку первинної інформації використовуються єдині формати документів, велика увага приділяється забезпеченню точності введеної інформації та наданню юридичної сили електронним документам за допомогою електронного цифрового підпису (далі - ЕЦП).

CD IS використовують комп'ютерні мережі різної архітектури та масштабу: однорангові і серверні 


\section{КОМП'ЮТЕРНІ НАУКИ ТА ІНФОРМАЦІЙНІ ТЕХНОЛОГІЇ № 4-2021}

комп'ютерні мережі типу «файловий сервер», «клієнт-сервер», а також інтранет, якщо учасники страхової діяльності територіально розподілені, і екстранет, якщо вони є представниками різних компаній (рис. 3).

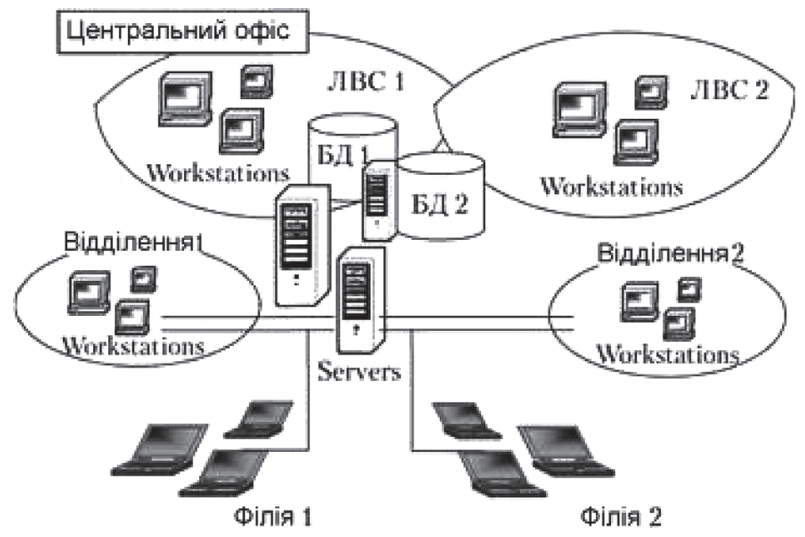

Рис. 3. Корпоративна мережа CD IS[2]

У центральному офісі (основна структура страхової компанії) є швидкісні локальні мережі, мережеві бази даних, централізований моніторинг мережевих ресурсів розподіленої комп'ютерної системи страхової компанії. Страхові компанії не використовують локальну мережу, віддалені користувачі використовують ноутбук із модемом, електронну пошту можна використовувати для зв'язку зі штаб-квартирою, а також віддалений доступ (VPN - Virtual Private Network). Ядром CD IS є база даних, керована базою даних, вибір якої залежить від успіху системи. Використовується для невеликих баз даних, що обслуговують невелику кількість користувачів (додатків), якщо вимоги до ефективності усунення несправностей не відрізняються від звичайних, так званих настільних СУБД реляційного типу (Access, Paradox, FoxPro та ін.). Для великомасштабних мережевих баз даних, що обслуговують значну кількість одночасних користувачів, використовуються мережеві реляційні мережі, як-от Oracle, MS SQL Server, DB2, Informix та ін. База даних великої страхової компанії створюється як розподілена база даних, що містить різноманітну інформацію про клієнтів, договори, страхові справи, виплати тощо протягом тривалого часу. Фрагменти БД представлені на різних комп'ютерах (вузлах мережі), ресурси СУБД підтримують «прозорість» розподілу даних. У підрозділах страхової компанії може бути створено декілька локальних баз даних, у яких загальна нормативнодовідкова інформація передається 3 центральної бази даних у вигляді реплік. Відповідно до встановленого регламенту локальні бази даних періодично «скидаються» в базу даних штабу (рис. 4). У роботі страхових компаній усе більшої популярності набувають інформаційні технології Інтернету, як-от електронна пошта, електронний сервіс новин на основі протоколу Usenet; пошук інформації в джерелах інформації всес- вітньої павутини (WWW), представлених у форматі HTML, і сумісних додатках (.asp, java, XML, Perl, PHP тощо) на основі протоколу НТТР, віддалений доступ до ресурсів комп’ютера на протокол Telnet тощо. Для великомасштабних БД IC СД обов'язкове виконання сервісного обслуговування: створення страхової копії БД, відновлення БД, ведення журналу транзакцій, надання авторизованого доступу до БД. Велика увага приділяється інформаційній безпеці та захисту даних від несанкціонованого доступу. На етапі обробки даних використовується програмне забезпечення системного та прикладного типу. Програмне забезпечення типу страхового бізнесу можна розділити на класи: офісні програми (текстові редактори, електронні таблиці, СУБД, графічні редактори, видавничі системи, інтернет-браузери тощо); програми для розв'язування задач із використанням математичних, статистичних методів аналізу та прогнозування, управління проєктами, функціональні програми. Публікація даних SD забезпечує зв'язок між страховою компанією та іiі клієнтами - страхувальниками (фактичними та потенційними). Зміст опублікованої інформації складають рекламні матеріали, зовнішні звітні документи, відповіді на запитання клієнтів тощо. Страхові компанії створюють вебсайти, для управління страхуванням організовано внутрішній вебсервер, доступ до якого заблоковано для не бізнес-користувачів за допомогою програмного забезпечення FireWall. Більшість програм, що забезпечують вирішення функціональних проблем страхової діяльності, представлені у вигляді вебсторінок (HTML), вебархіву (MHTL), XML [3].

\section{РЕЗУЛЬТАТИ}

У процесі дослідження охарактеризовано структуру комп'ютерної інженерії страхової компанії. Проаналізовано наявні структурні моделі автоматизованої інформаційної системи. У результаті аналізу розраховано рисунки та діаграми характерної комп'ютерної інженерії страхової компанії.

\section{ОБГОВОРЕННЯ ОТРИМАНИХ РЕЗУЛЬТАТІВ}

У розвинених країнах світу поряд із вебсайтами окремих компаній існують страхові портали, де зібрана інформація найбільших страхових компаній, рейтинги компаній, можна ознайомитись 3 умовами, вибрати кращі пропозиціі. Існують також мініпортали (2-10 компаній), які спеціалізуються на окремих видах страхування, інтегрують учасників проєкту в одну віртуальну страхову систему, що працює в онлайн-режимі. Користувач може порівняти умови і ціни різних страховиків на ті ж види послуг, ознайомитись із рейтингами страхових компаній, творцями порталів.

Інтернет не тільки сприяєиме появі нових страхових продуктів та прогресивних бізнес-моделей обслуговування клієнтів, а й забезпечить вихід страхової компанії на новий сегмент фінансового ринку і приведе до глобалізації страхового бізнесу. 
Нині з'явились нові види послуг інтернет-страхування ризиків: наслідки кіберзлочинності; виведення 3 ладу інформаційних мереж; порушення цілісності БД і прикладних систем; фінансування ризиків у системах електронної комерції; різні види відповідальності (наприклад, за недоброякісну рекламу в мережі Інтернет, розголошення конфіденційних даних, номери кредитних карток тощо).
Майбутнє інтернет-страхування цікавить багатьох як середовище для ділових операцій.

\section{ВИСНОВКИ}

Результатом дослідження є характеристика структури комп'ютерної інженерії страхової компанії, наявні структурні моделі автоматизованої інформаційної системи в Україні.

\section{REFERENCES}

[1] Zakon Ukrainy "Pro strakhuvannia" \# 85/96ᄀVR vid 07.03.1996 r. (zi zminamy ta dopovnenniamy). URL: http://zakon2.rada.gov.ua/laws/show/85/96 $\%$ D0\%B2\%D1\%80 (data zvernennia: 11.03.2021).

[2] Rohan Agarwal. Solvency: Meaning and Important Ratios. Your article library. The next generation library. 2019. P. 1-105.

[3] Bondarenko P.V Sutnist finansovoho potentsialu strakhovoi kompanii. International journal "European Journal of Economics and Management”. 2021. \#3. URL: https:/eujem.cz/ (data zvernennia: 06.05.2021).

\section{СПИСОК ВИКОРИСТАНОЇ ЛІТЕРАТУРИ}

[1] Закон України «Про страхування» від 07 березня 1996 р. № 85/96-BP (зі змінами та доповненнями). URL: http://zakon2.rada.gov.ua/laws/show/85/96\%D0\%B2\%D1\%80 (дата звернення: 11.03.2021).

[2] Rohan Agarwal. Solvency: Meaning and Important Ratios. Your article library. The next generation library. 2019. P. 1-105.

[3] Бондаренко П.В Сутність фінансового потенціалу страхової компанії. International journal "European Journal of Economics and Management”. 2021. № 3. URL: https://eujem.cz/ (дата звернення: 06.05.2021).

(C) Бондаренко В. Г., Бондаренко П. В. Дата надходження статті до редакції: 15.11 .2021 Дата затвердження статті до друку: 29.11.2021 